\title{
Os labirintos da estratégia
}

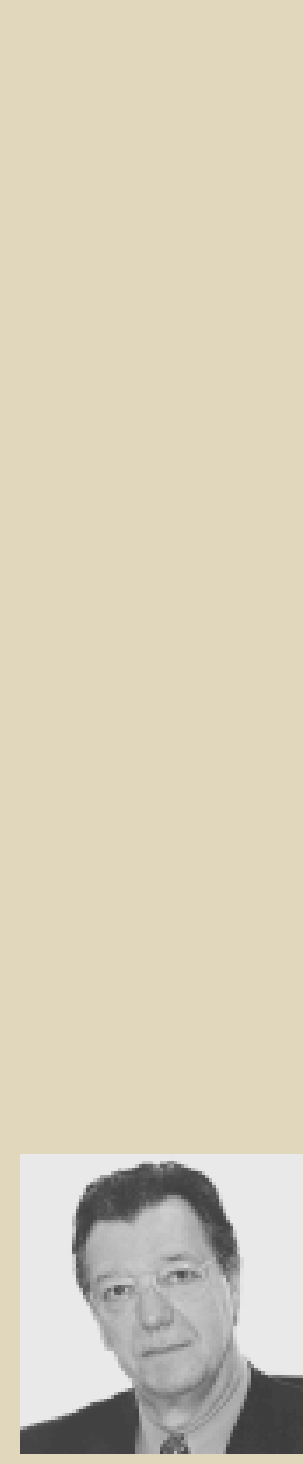

Carlos Osmar Bertero FGV-EAESP

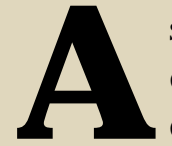

$s$ duas entrevistas a seguir, realizadas com os professores Jay Barney e Richard W hittington, ajudarão os leitores a entender um pouco melhor os caminhos e labirintos da gestão estratégica. São duas maneiras distintas de abordar a questão, embora não-conflitantes.

Jay Barney é, em boa medida, responsável pelo desenvolvimento da concepção de que a estratégia deve sempre derivar dos recursos que a própria empresa possui. Com isso, a análise das perspectivas econômicas e do ramo de atividades, especialmente a atenção devotada aos concorrentes, passa a ocupar lugar secundário nas preocupações dos responsáveis pela gestão estratégica da empresa. 0 trabalho de Barney procura mostrar que a "visão baseada em recursos" é a melhor maneira de gerir estrategicamente e que tal perspectiva pode se tornar um instrumento eficaz na formulação de estratégias voltadas para 0 desenvolvimento de vantagem competitiva sustentável.

A proposta de Richard Whittington, conforme podemos observar, é distinta. 0 pesquisador inglês argumenta que a gestão estratégica é um sinônimo de administração, pura e simplesmente. Para ele, a gestão estratégica não possui um modelo (e nem parece acreditar que ele exista) e tampouco acredita que teorias precedem a prática. Em sua visão, a teoria nasce da prática. Além disso, segundo Whittington, não podemos encontrar, no mundo dos negócios, receitas claras e generalizáveis. A conclusão que se segue é a de que estratégias tendem a ser emergentes, nascendo a partir da organização.

Assim, é praticamente impossível determinar quem foi responsável por uma determinada estratégia e quando ela foi decidida ou formulada. Whittington acredita que as empresas estão repletas de estrategistas e que o fundamental é saber aproveitar e canalizar os talentos e as idéias de todos eles. Afinal, pensar estrategicamente não é privilégio de uma minoria, seja de acionistas, conselheiros, diretores, superintendentes ou consultores bem remunerados.

Os dois entrevistad os apontam também características e formas de administrar que incorporam estilos nacionais. Os norte-americanos acreditam que, onde houver desejo, decisão e bons instrumentos, serão produzidos resultados. É o estilo do pragmatismo-yankee. Os ingleses também são pragmáticos, mas não acreditam no efeito miraculoso da determinação norte-americana eno uso de modelos. Para eles, prazos podem não fazer muito sentido e as narrativas heróicas de como uma determinada estratégia foi decidida parecerá mais uma história contada posteriormente para colorir um percurso longo, difícil e tortuoso. Enfim, deixamos o leitor com esses dois professores que têm trazido idéias interessantes e provocativas sobre os caminhos da gestão estratégica. 